\title{
A NEW APPROACH TO WESTINGHOUSE TEMPO RATING SYSTEM WITH FUZZY LOGIC
}

\author{
Alper KIRAZ ${ }^{*}$, Merve CENGIZ TOKLU², Mehmet Riza ADALI ${ }^{3}$ \\ ${ }^{1}$ Sakarya Üniversitesi, Mühendislik Fakültesi, Endüstri Mühendisliği Bölümü, Sakarya \\ ORCID No: https://orcid.org/0000-0001-7067-1473 \\ 2Sakarya Üniversitesi, Mühendislik Fakültesi, Endüstri Mühendisliği Bölümü, Sakarya \\ ORCID No : https://orcid.org/000-0001-9609-5136, \\ 3Sakarya Üniversitesi, Mühendislik Fakültesi, Endüstri Mühendisliği Bölümü, Sakarya \\ ORCID No : https://orcid.org/0000-0002-3678-5861
}

\begin{tabular}{|c|c|}
\hline Keywords & Abstract \\
\hline $\begin{array}{l}\text { Tempo rating system, } \\
\text { Classical Westinghouse } \\
\text { method, normal time, fuzzy } \\
\text { logic, Fuzzy Westinghouse } \\
\text { method }\end{array}$ & $\begin{array}{l}\text { When calculating the production cost of a product, two basic items are taken into } \\
\text { consideration. The first is the material cost and the second is the labor cost. Material } \\
\text { costs can be calculated very clearly due to the lack of personal judgment. Because the } \\
\text { amount of material used for the production of that product is certain. However, the } \\
\text { calculation of labor costs may not always be as simple and precise. The amount of } \\
\text { product produced per unit time directly affects product costs. Therefore, to calculate } \\
\text { the costs correctly, the number of parts produced per unit time must be calculated } \\
\text { correctly. At this point, production times per product gain importance. It is not } \\
\text { considered sufficient to use the values on the chronometer when calculating the } \\
\text { production times of parts or products. Standard production times are calculated by } \\
\text { adding performance and tolerance values to the chronometer values. Worker } \\
\text { performance may vary from person to person. Performance varies depending on } \\
\text { worker ability, effort, consistency and working environment. This difference in } \\
\text { performance becomes very important in manual production processes. In automatic } \\
\text { production processes, this difference is especially important when disassembling and } \\
\text { assembly processes of the parts to the automatic machines. Tempo rating systems } \\
\text { have been proposed to standardize worker performances and to minimize the } \\
\text { negative effects of performance differences between individuals. The Classical } \\
\text { Westinghouse Method (CWM) is one of the common use tempo rating system. In the } \\
\text { CWM, the performance of the worker is calculated by using skill, effort, } \\
\text { environmental conditions, and consistency values. Evaluations of these four criteria } \\
\text { are obtained by observing by decision-makers. In this study, the fuzzy rule-based } \\
\text { Westinghouse method is developed because decision-makers use linguistic } \\
\text { expressions to evaluate worker performance. The proposed Fuzzy Westinghouse } \\
\text { Method (FWM) is applied to a part of the company that produces automatic cutting } \\
\text { machines in order to prove its validity. As a result of the study, it is determined that } \\
\text { the proposed model produces more sensitive values. }\end{array}$ \\
\hline
\end{tabular}

\section{WESTINGHOUSE TEMPO DERECELENDİRME SISTEMINE BULANIK MANTIK İLE YENI BİR} YAKLAȘIM

\begin{tabular}{ll}
\hline Anahtar Kelimeler & Öz \\
\hline Tempo derecelendirme & Bir ürünün üretim maliyeti hesaplanırken iki temel öge dikkate alınır. Bunlardan \\
sistemi, klasik Westinghouse & birincisi malzeme maliyeti ve ikincisi işçilik maliyetidir. Kişisel muhakeme eksikliği \\
metodu, normal zaman, & nedeniyle malzeme maliyetleri çok net bir şekilde hesaplanabilir. Cünkü o ürünün \\
bulanık mantık, bulanık & üretimi için kullanılan malzeme miktarı bellidir. Bununla birlikte, işçilik \\
Westinghouse metodu & maliyetlerinin hesaplanması her zaman bu kadar basit ve kesin olmayabilir. Birim \\
& zamanda üretilen ürün miktarı, ürün maliyetlerini doğrudan etkiler. Bu nedenle \\
& maliyetleri doğru hesaplamak için birim zamanda üretilen parça adedinin doğru \\
& hesaplanması gerekir. Bu noktada ürün başına üretim süreleri önem \\
\hline
\end{tabular}

*Sorumlu yazar; e-posta: kiraz@sakarya.edu.tr 
kazanmaktadır. Parça veya ürünlerin üretim süreleri hesaplanırken kronometredeki değerlerin kullanılması yeterli görülmemektedir. Standart üretim süreleri, kronometre değerlerine performans ve tolerans değerleri eklenerek hesaplanmaktadır. Çalışan performansı kişiden kişiye değişebilir. Performans, çalışanın yeteneğine, çabasına, tutarlılığına ve çalışma ortamına bağlı olarak değişmektedir. Performanstaki bu fark, manuel üretim süreçlerinde çok önemli hale gelmektedir. Otomatik üretim süreçlerinde bu fark özellikle parçaların otomatik makinelere demontaj ve montaj işlemlerinde önemlidir. Çalışan performanslarını standartlaștırmak ve bireyler arasındaki performans farklıllklarının olumsuz etkilerini en aza indirmek için tempo derecelendirme sistemleri önerilmiştir. Klasik Westinghouse metodu, yaygin kullanilan tempo derecelendirme sistemlerinden biridir. Klasik Westinghouse metodunda işçinin performansı beceri, çaba, çevre koşulları ve tutarlılık değerleri kullanılarak hesaplanır. Bu dört kriterin değerlendirmeleri karar vericiler tarafindan gözlemlenerek elde edilir. Bu çalışmada, karar vericilerin çalışan performansını değerlendirmek için dilsel ifadeleri kullanması nedeniyle bulanık kural tabanl Westinghouse metodu geliştirilmiștir. Önerilen bulanık Westinghouse metodu, geçerliliğini kanıtlamak için otomatik kesme makineleri üreten şirketin bir bölümüne uygulanmaktadır. Çalışma sonucunda önerilen modelin daha hassas değerler ürettiği tespit edilmiștir.

Araştırma Makalesi

Başvuru Tarihi

Kabul Tarihi
: 12.10 .2020

: 06.02.2021
Research Article

Submission Date

Accepted Date
: 12.10 .2020

: 06.02.2021

\section{Introduction}

The main purpose of every profit-oriented business is to make a profit by producing products and/or services and offering them to the end user. In the simplest way, profit is obtained by subtracting production costs from the sales price of the product. The rise in production costs results in higher prices in a fixed profit margin. If the market of the product determines the price, then the rising costs will reduce the profit margin. In today's competitive business world, companies need to keep production costs as low as possible in order to sustain their market presence. First of all, it is very important to calculate the cost of parts correctly. For example, if the cost of a product is underestimated, this will result in a low price recommendation to the customer. In this case, lower profits can be made and even financial losses can be obtained. On the contrary, if the costs are calculated higher than they are, then the product price will be increased and fewer customers will be reached. Unit product costs are influenced by different factors such as product quality, labour and technology used, product design. In this direction, production costs can be reduced by increasing labour productivity as a result of standardization, simplification, and elimination of activities that do not add value. The work-study approach has been developed for this purpose.
The work study consists of two main techniques: method study and time study. The purpose of the method study is to eliminate non-value added processes and to obtain the fastest and most accurate method of performing value added processes. Time study is a methodology in which the time duration of each activity of a subject is recorded in order to create the workflow and achieve efficiency and effectiveness through eliminating waste and simplifying work (CheboluSubramanian, Sule, Sharma, Mistry 2019). Firstly, a process should be standardized with the method study, then the production times should be determined by the time study. In this study, the proposed method is developed to use in time study activities.

The main activities of the work-study method are shown in Figure 1. Firstly, the product or part on which the work-study method will be applied is determined. When determining this part, it is useful to give priority to the problematic parts that create bottlenecks in production. The second stage is a critical examination of the production stages of the product in full detail within the scope of the method-study. The most suitable method for the production of the related product is determined by developing solutions for the problems occurring during the production phase. Then the method is documented and standardized. After the 
determination of most appropriate method and elimination of non-value added processes by the method-study, the time study phase is started. In the time study method, the observer first measures the production times. These times are called chronometer values (CV) because these values are read directly from the chronometer. Performance and tolerance coefficients are not added. In the next step, the performance value (P) of the observed worker is determined using any tempo rating method. Normal Time (NT) is obtained by multiplying this determined performance value with the chronometer value measured by the observer (Eq. 1).

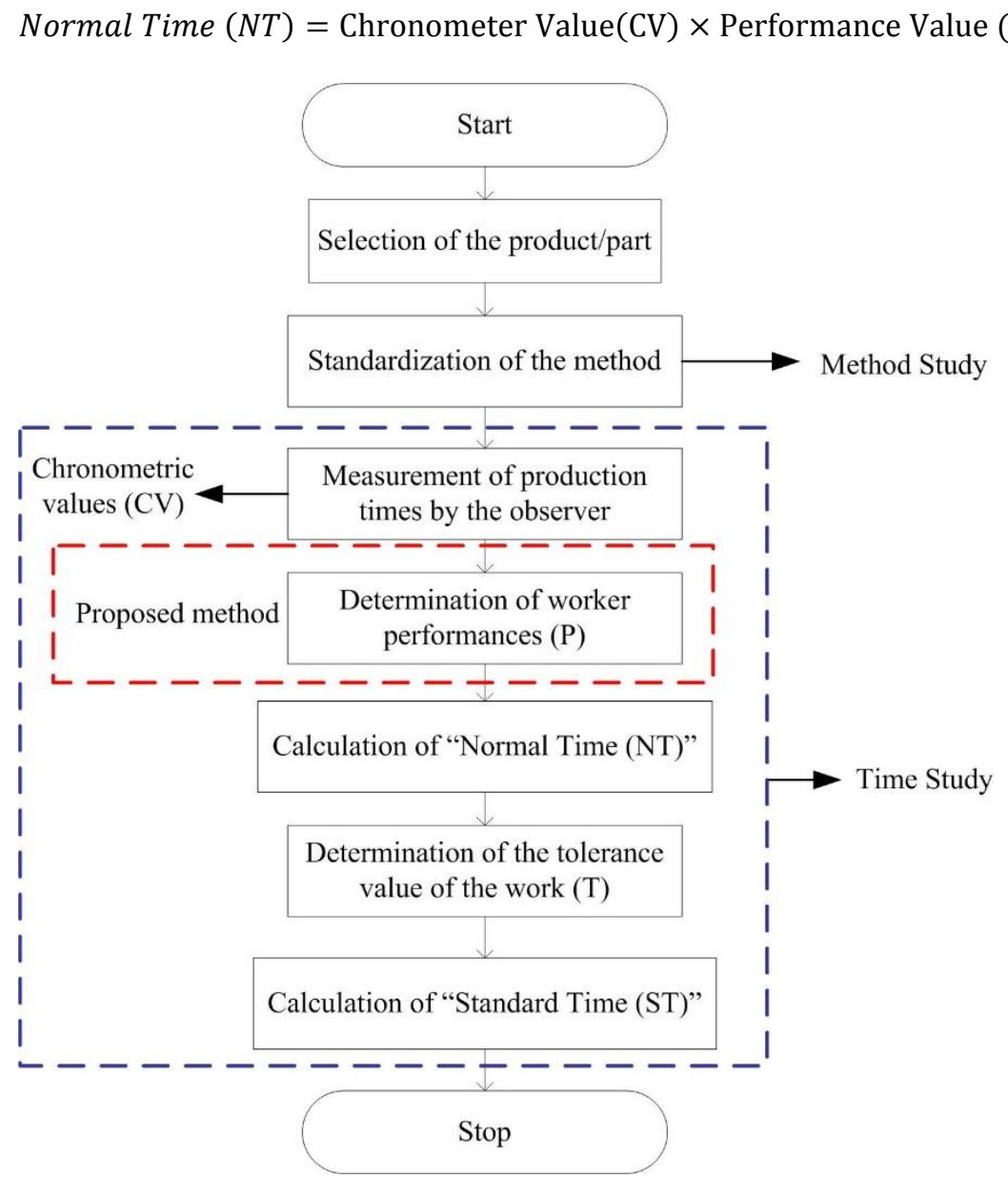

Figure 1. Main activities of the work-study method

Next, A Tolerance Value (T) is determined by considering the weight of the part to be observed, the temperature of the working environment, the working position, noise, vibration in the working environment. In the last phase, the Standard Time (ST) is obtained by multiplying the Normal Time with the Tolerance Value. Standard Times are used for all cost calculations or for calculation of production times (Eq. 2). 
This study proposed a suggestion for the tempo rating method used to determine performance in the time study method. Tempo rating is the evaluation of the working speed of the worker according to the standard speed concept of the observer. This standard is the normal speed that qualified workers can achieve with normal work (Bircan and İskender 2005).

The Classical Westinghouse Method (CWM) is one of the tempo rating methods. CWM is based on four factors which are skill, effort, environmental conditions, and consistency (Lehto and Landry 2012). In the CWM, numeric values are used instead of linguistic variables while determining the performance value. However, these numerical values are defined as intermittent values. For instance, according to the skill factor, a worker should have a value between +0.15 and +0.13 to be considered "Perfect". Similarly according to the skill factor, a worker should have a value between +0.11 and +0.08 to be considered "Excellent". As can be seen in Table 1 there is no a linguistic equivalent for the +0.12 value between "Perfect" and "Excellent" for skill factor in the CWM. It is aimed to obtain an alternative of CWM that can produce more precise results by ensuring intermediate values. In the proposed method the intermediate values is taken into consideration by using fuzzy logic approach. Thus, it is aimed to obtain more realistic values for each limit value between "Excellent" and "Poor" levels of four factors that used in the CWM. This study aims to standardize linguistic expression of the evaluator in ambiguity situations by using the fuzzy logic technique. There are two studies in the literature about the CWM handled with the fuzzy approach. Çevikcan et al. (Çevikcan, Kılıç, Zaim 2012) proposed a fuzzy model with two factors (skill and effort) of CWM for determining the performance values. In another study, Çevikcan and Kılıç (Çevikcan and Kılıç 2016) proposed a fuzzy model with three factors (skill, effort and environmental conditions) for determining the performance values. In this study, a more holistic model (including each four factor of CWM) with fuzzy rules is proposed to determine the performance values.

\section{Performance Rating}

While the operator is working during a task, evaluation of the speed, pace or the tempo (the terms are used synonymously to refer to the speed of movement) is an important part of the time study. The operators speed must be judged by the analyst during the time working. This is called performance rating. There are several methods that is used for performance rating (Lehto and Landry 2013). These are briefly described below (Barnes 1980; Suwittayaruk, Van Goubergen, 2011).

Synthetic Rating: This method effort to provide a rating that is not influenced by human judgments by using predetermined time values which were evaluating an operator's speed. Performance rating factor can be found by the ratio of predetermined time value and the actual time value of an element. The computation of the performance rating factor's formula is given below (Eq. 3) (Barnes 1980; Matias 2001).

$R=P / A$

where

$\mathrm{R}=$ Performance Rating Factor

$\mathrm{P}=$ Predetermined Time for the element

$A=$ Average Actual Time for the same element

Thus the determined factor can be applied to other manual elements being studied.

Objective Rating: The purpose of this method is to reduce the amount of judgement in the time study. The procedure of this method is consist of two steps (Barnes 1980; Matias 2001);

a. The degree of speed observed to an objective speed standard that is the same for all jobs. In this rating, attention is not paid to the difficulty of work and its limiting effect on possible speed; therefore, a single tempo standard can be used instead of multiple mental concept.

b. Not all jobs can be performed at standard pace, because in practice they will all be more or less difficult than the job where standard pace is created. The factors affecting the pace of work, as indicated by experimental or practical evidence, are as follows as:

- Total amount of body involved in the element

- Foot pedals

- Bimanualness

- Eye-Hand Co-ordination

- Handling requirements

- Weight handled or the resistance encountered 
Performance Rating: This method known as "Speed Rating" or "Effort Rating". In this method, the time study analyst only takes into account the success rate per unit time. The analyst compares the performance displayed with its normal performance concept for the operation under examination (Barnes 1980; Matias 2001).

Physiological Rating: Physiologists demonstrated the validity of using the oxygen consumption rate to measure energy consumption. Subsequent studies have shown that the change in heart rate is also a reliable measure of physical activity. In this method, the change in heart rate and oxygen consumption values of a worker while performing a job is determined as tempo (Barnes 1980; Matias 2001).

In this study, performance rating approach of CWM is discussed. CWM is developed by Westinghouse Company in 1927 (Bircan and İskender 2005). The need for full understanding and adequate training is strongly emphasized in the use of the technique to achieve consistent and accurate results. The system gives numerical weights to skill, effort, conditions, and consistency as found during a study. To what extent variables affect the productivity of an employee helps the analyst to make a more precise overall assessment. It is important to understand the concepts of skill, effort, conditions and consistency before the application of the method (Matias 2001).

Table 1

Rating Points of CWM (Lehto and Landry 2012)
The skill defined as "the ability to follow a given method" can be further explained by associating it with the craftsmanship shown by the proper coordination of the mind and hands. The effort can be described as "Being ready to work" or the willingness of an employee to spend energy in an effective job is a complex of human behavior that is worthy of close attention by industrial engineers. People work in conditions or environments that directly affect their productivity. The important factor in the following conditions is not what their absolute values can be, but whether a condition or other condition is normal and the best factor that can be achieved for the work done. Consistency is considered a factor that draws attention to the extent or lack of consistency. Instead of classifying, it is better to identify and correct the cause. Consistency may be seen as a small factor when it comes to the shares of other factors.

As the time study analyst observes the operator, the analyst notes the skills, effort, consistency, and conditions for each job along with their codes. The numerical degree of factors is then algebraically added to the nominal 100 percent to produce a finished rating (Matias 2001). The linguistic variables of the rating factors and their performance values are given in Table 1 .

\begin{tabular}{ccccccccc}
\hline Level & \multicolumn{2}{c}{ Skill } & \multicolumn{2}{c}{ Effort } & Conditions & Consistency \\
& & & & & & & & \\
\hline Perfect & A1 & 0.15 & A1 & 0.13 & A & 0.06 & A & 0.04 \\
& A2 & 0.13 & A2 & 0.12 & & & & \\
Excellent & B1 & 0.11 & B1 & 0.10 & B & 0.04 & B & 0.03 \\
& B2 & 0.08 & B2 & 0.08 & & & & \\
Good & C1 & 0.06 & C1 & 0.05 & C & 0.02 & C & 0.01 \\
& C2 & 0.03 & C2 & 0.02 & & & & \\
Average & D & 0 & D & 0 & D & 0 & D & 0 \\
Fair & E1 & -0.05 & E1 & -0.04 & E & -0.03 & E & -0.02 \\
& E2 & -0.10 & E2 & -0.08 & & & & \\
Poor & F1 & -0.16 & F1 & -0.12 & F & -0.07 & F & -0.04 \\
& F2 & $-0,22$ & F2 & -0.17 & & & & \\
\hline
\end{tabular}

CWM is useful in other ways. For example, the skill factor provides a basis for estimating the potential benefits of training if one can estimate the change in skill resulting from the training program. Similarly, the effort factor might be useful to evaluate a prospective incentive program, and the conditions factor allows for an estimate of performance due to changes in working conditions (Lehto and Landry 2012) 


\section{The Proposed Method}

Fuzzy Westinghouse Method (FWM) includes 4 input and 1 output parameter. The input parameters of the FWM are determined as "Skill", "Effort", "Working Conditions" and "Consistency" to

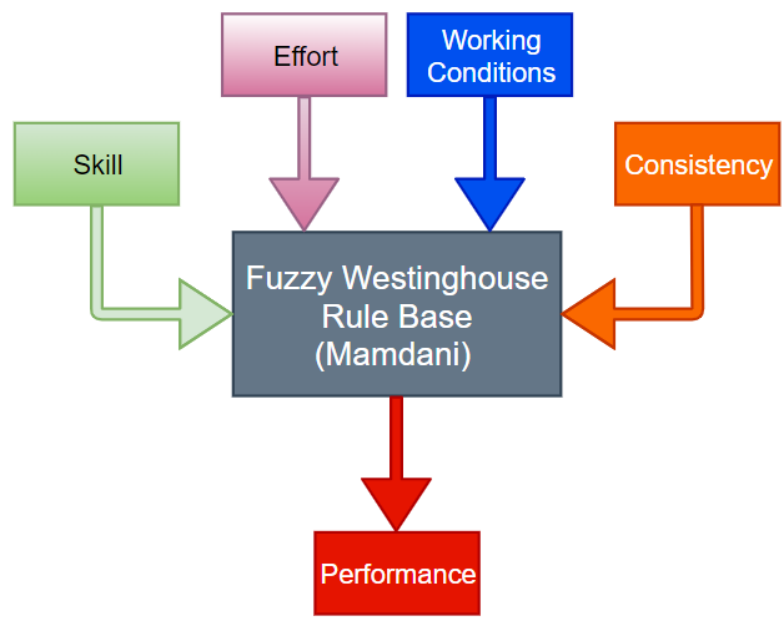

Figure 2. Fuzzy rule based system for performance

CWM includes 5 levels for determining the performance of operators. These levels; Poor, Fair, Average, Good, Excellent, Perfect; are integrated to create membership function. Membership functions have both triangular and trapezoidal fuzzy numbers and these are determined by taking into consideration points of CWM, shown in Table 1 . Interval values of membership functions are shown in Table 2. The rating scale adopted in the CWM is

Table 2

Interval Values of Membership Functions

\begin{tabular}{cllllll}
\hline & & Poor & Fair & Average & Good & Excellent
\end{tabular}

In this study, Mamdani fuzzy inference system (Mamdani and Assilian 1975) is used and the model meet the CWM. The output parameter of the FWM is "Performance". Furthermore, due to the fact that consistency is regarded all parameters of CWM are included in "Performance" value. This value is attempted to be determined by considering these 4 main input parameters shown in Figure 2. used creating the membership functions to be attain consistent minimum and maximum values. For instance, range of the Skill [78, 115], Effort [83, 113], Working Conditions [93, 106] and Consistency $[96,104]$ are evaluated within these range in the FWM. Considering these ranges of the input parameters, the output parameter of the model, Performance, is evaluated as range of $[50,135]$. is created using fuzzy logic toolbox of Matlab software. Due to the lack of training set and the 
characteristic of the CWM, Mamdani model structure is developed on the basis of expert knowledge and training. In the proposed model, "and" /"or" processes (Eq. 4, Eq. 5) which are

$$
\begin{gathered}
\mu A(x) \text { and } \mu B(x)=\operatorname{MIN}\{\mu A(x), \mu B(x)\} \\
\mu A(x) O R \mu B(x)=M A X\{\mu A(x), \mu B(x)\} \\
\mu R(x, y)=\operatorname{MIN}\{\mu A(x), \mu B(x)\} \\
\mu R(x, y)=\operatorname{MAX}\{1-\mu A(x), \operatorname{MIN}\{\mu A(x), \mu B(x)\}\}
\end{gathered}
$$

established between fuzzy rules "min" / $m a x "$ values (Eq. 6, Eq. 7) are preferred respectively (Pourjavad and Mayorga 2019).

There are many defuzzification methods as center of gravity, bisector of area, smallest of maximum, mean of maximum and largest of maximum etc. For subtraction "min", for addition "max" and for defuzzification "largest of maximum (LOM)" specifications are defined. In this study, LOM, which has maximum membership to the overall implied
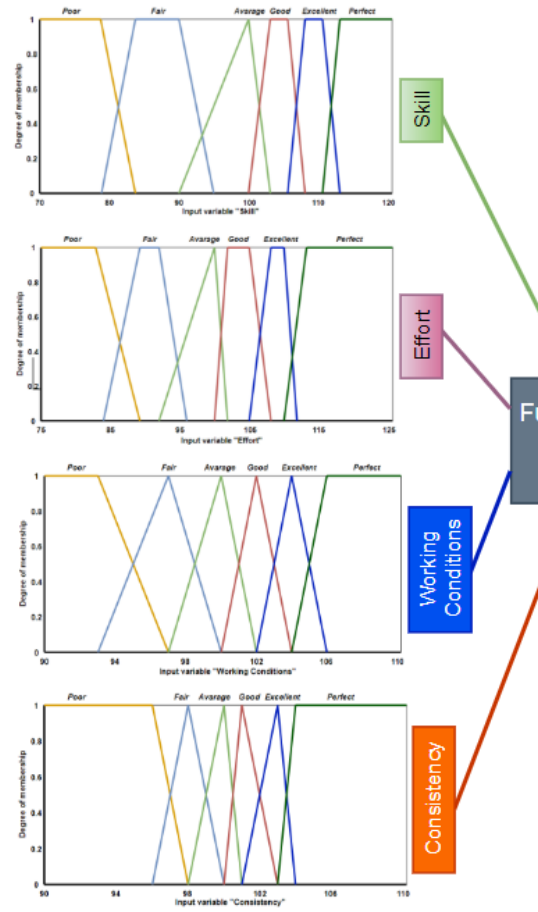

Figure 3. Inputs and Output of Proposed Model

fuzzy set is preferred. This defuzzification method where crisp value is calculated as Eq. 8 (Namazov and Bastürk 2010). Structure of proposed model is shown in Figure 3.

$u_{L O M}=x_{\max }$ 
Triangular and trapezoidal membership functions are both used for membership functions and showed as overlapped. The membership functions of inputs are presented in Figure 4. The

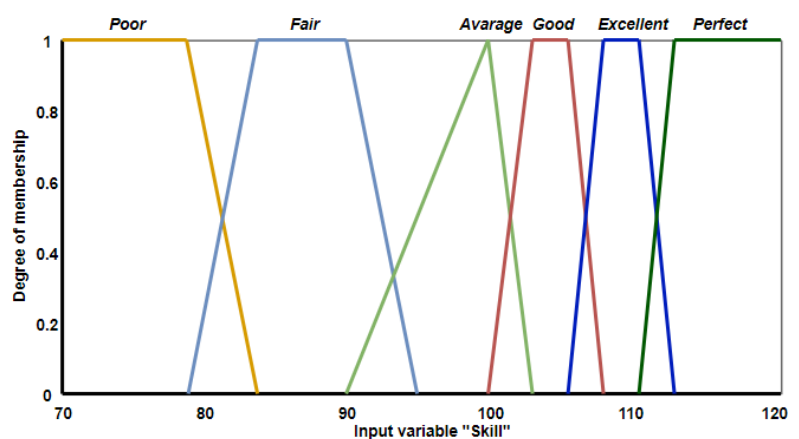

(a) Skill

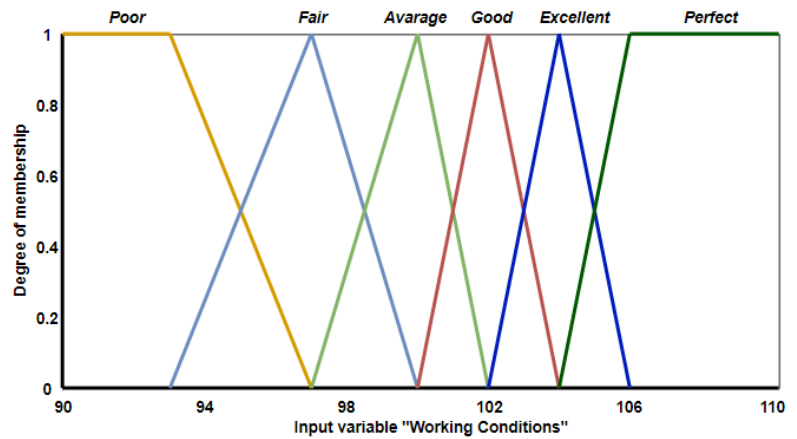

(c) Working Conditions

Figure 4. Membership functions of inputs

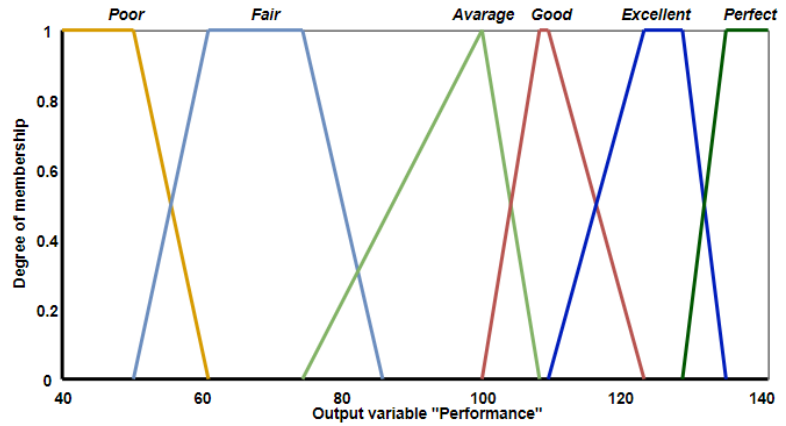

Figure 5. Membership functions of output membership functions of "Performance" are presented in Figure 5.

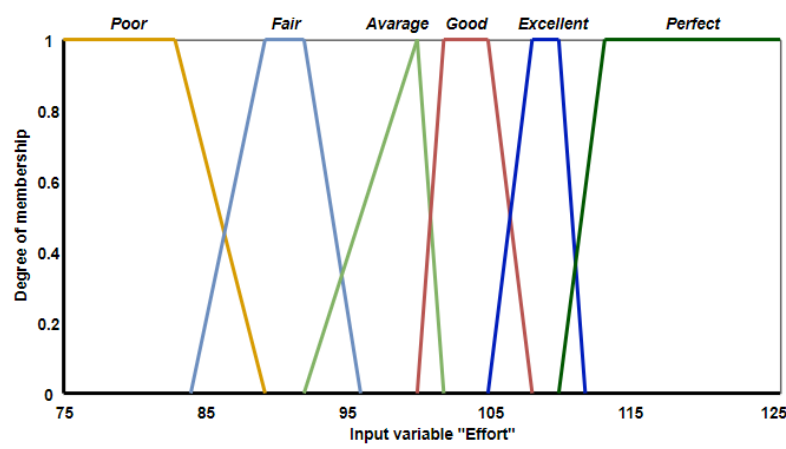

(b) Effort

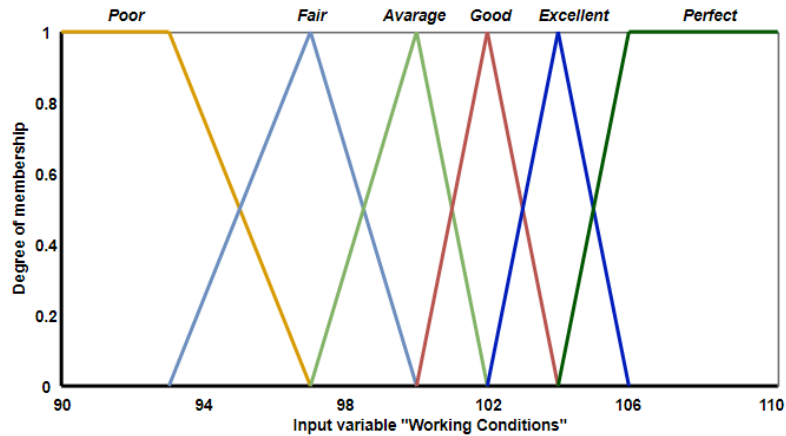

(d) Consistency

In the proposed model 491 rules are generated for Performance according to the relationship between state and control variables by the experts. Rules are generated via the judgments of three industrial engineers having 10-15 year experience about work study. The rule base is briefly shown in Figure 6(a). Performance result of state variables for any value in the predefined ranges are obtained as in Figure 6(b). 


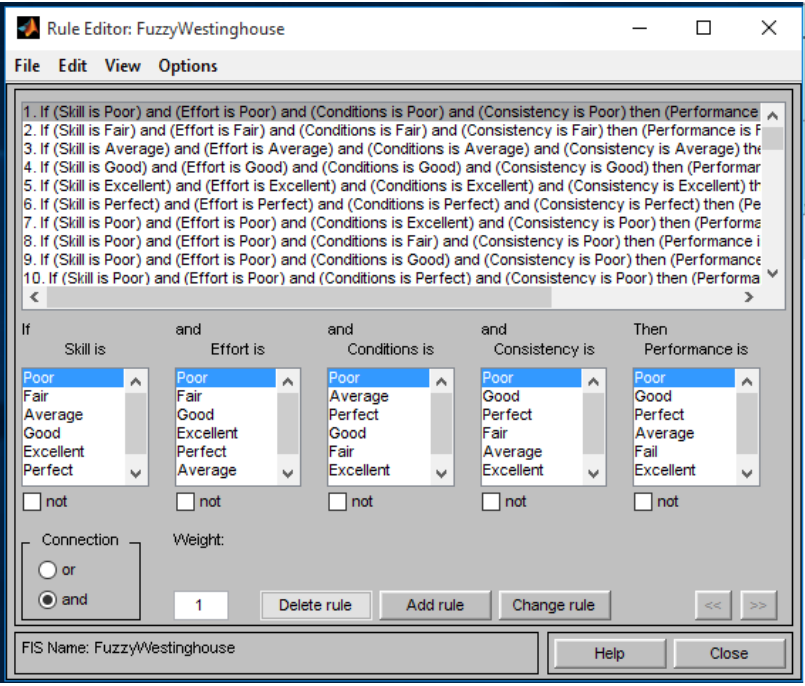

(a)

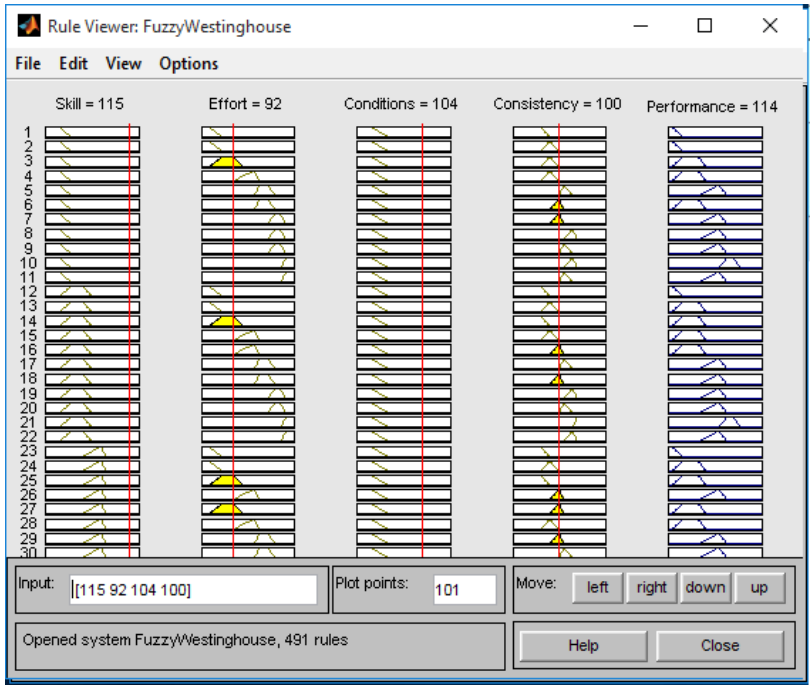

(b)

Figure 6. (a) Rule base, (b) Performance evaluation display

\section{Application of the Proposed Method}

The proposed FWM is applied in a machine manufacturing company. Work-study process is carried out on an important part of the machine. This part which is the connection element of the

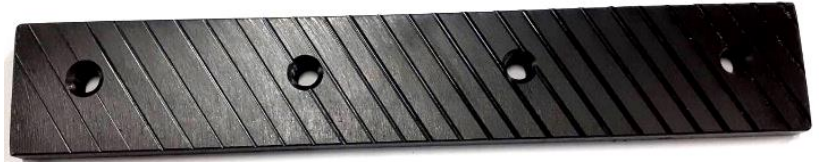

machine is called sheet bar. The part and technical drawing are presented in Figure 7. Ethics committee approval was not required in the study, research and publication ethics were followed.

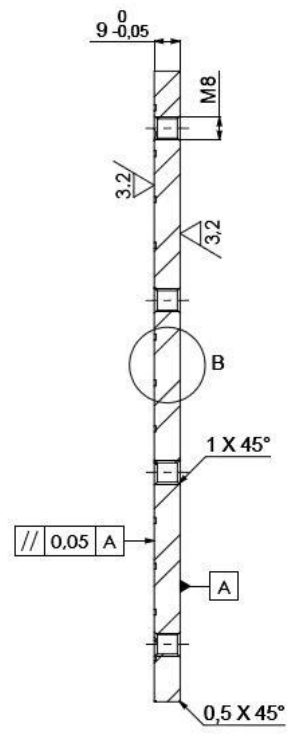

SECTION A-A

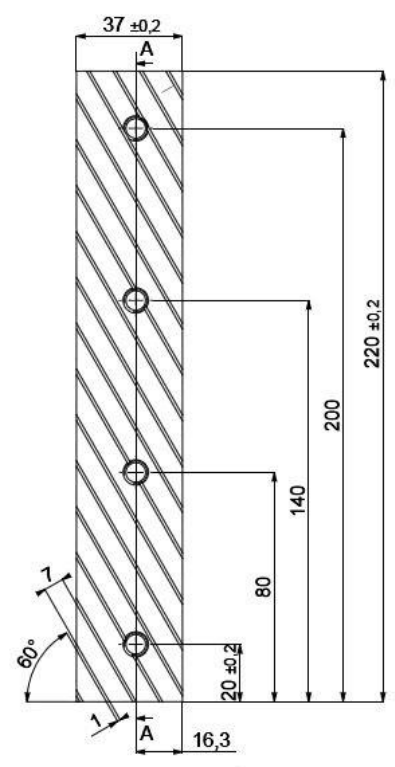

(b)

Figure 7. (a) the part: sheet bar (b) technical drawing of the part 
The part is assembled to the product at the end of 5 operations after coming to the plant as raw material. These operations are cutting, universal milling, CNC processing, universal milling, and metal blackening respectively. The number of observations should be determined before starting the observation process. The number of observations is calculated in the work-study area with Eq. 9 (5\% tolerance and 95\% confidence interval) (Kanawaty 1992).

$N=\left[\frac{40 \sqrt{n \sum x_{i}^{2}-\left(\sum x_{i}\right)^{2}}}{\sum x_{i}}\right]^{2}$

where $x_{i}$ : the value of $\mathrm{i}^{\text {th }}$ trial observation of the related operation

$\mathrm{n}$ : the number of trial observations

$\mathrm{N}$ : the number of required observations to predict within the desired sensitivity and confidence interval

Trial observations are performed to determine the number of observations required. In the literature, a certain amount is not determined for the number of trial observations. In this study, 5 experimental observations are made. The values of 5 trial observations are given in Table 3. Table 3 identifies the number of required observations for each process. These numbers vary between 5 and 13. In this study, the number of observations required for each process is 15 .

Table 3

The values of trial observations

\begin{tabular}{cccccc}
\hline & Cutting & Universal Milling & CNC Processing & Universal Milling & Metal Blackening \\
\hline $\mathrm{n}_{1}$ & 19.3 & 480.5 & 298.3 & 70.3 & 120.9 \\
$\mathrm{n}_{2}$ & 20.1 & 475.8 & 302.1 & 69.9 & 122.1 \\
$\mathrm{n}_{3}$ & 21.2 & 476.8 & 299.3 & 68.7 & 118.7 \\
$\mathrm{n}_{4}$ & 20.1 & 479.3 & 301.4 & 67.9 & 119.3 \\
$\mathrm{n}_{5}$ & 20.3 & 481.9 & 303.9 & 70.3 & 121.9 \\
$\mathrm{~N}$ & 13 & 5 & 7 & 7 & 10 \\
\hline
\end{tabular}

In the next step, the performance values of the workers in each process are determined through observation. Performance values for the FWM are determined with Matlab software (Table 4).

Table 4

Performance values for CWM and FWM

\begin{tabular}{ccccccc}
\hline Process & Skill & Effort & $\begin{array}{c}\text { Env. } \\
\text { Cond. }\end{array}$ & Consis. & $\begin{array}{c}\text { Performance Value } \\
\text { for CWM }\end{array}$ & $\begin{array}{c}\text { Performance Value } \\
\text { for FWM }\end{array}$ \\
\hline Cutting & 113 & 102 & 102 & 101 & 118 & 115 \\
Universal Milling & 103 & 108 & 104 & 104 & 119 & 120 \\
CNC Processing & 106 & 105 & 104 & 101 & 116 & 112 \\
Universal Milling & 111 & 105 & 102 & 103 & 121 & 119 \\
Metal Blackening & 100 & 105 & 93 & 98 & 96 & 95 \\
\hline
\end{tabular}

15 observations are made for each process and standard times are calculated. According to the company policy, the tolerance value is determined as $115 \%$ for each process. The number of observations, numerical values of each factor affects the performance, performance value, normal time and standard time for CWM and FWM for each processes are shown in Table 5-Table 9. 
Table 5

Normal and Standard time for cutting process according to CWM and FWM

\begin{tabular}{|c|c|c|c|c|c|c|c|c|c|c|c|c|}
\hline Obs. & $\begin{array}{c}\text { Obs. } \\
\text { Time } \\
\text { for } \\
\text { Cutting }\end{array}$ & Skill & Effort & $\begin{array}{l}\text { Env. } \\
\text { Cond. }\end{array}$ & Cons. & $\begin{array}{l}\text { Performance } \\
\text { Value for } \\
\text { CWM }\end{array}$ & $\begin{array}{l}\text { Performance } \\
\text { Value for } \\
\text { FWM }\end{array}$ & $\begin{array}{l}\text { Normal } \\
\text { Time for } \\
\text { CWM }\end{array}$ & $\begin{array}{l}\text { Normal } \\
\text { Time for } \\
\text { FWM }\end{array}$ & Tolerance & $\begin{array}{l}\text { Std. Time } \\
\text { for CWM }\end{array}$ & $\begin{array}{l}\text { Std. Time } \\
\text { for FWM }\end{array}$ \\
\hline 1 & 19.9 & 113 & 102 & 102 & 101 & 118 & 115 & 23.482 & 22.885 & 115 & 27.0043 & 26.317 \\
\hline 2 & 19.5 & 113 & 102 & 102 & 101 & 118 & 115 & 23.010 & 22.425 & 115 & 26.4615 & 25.788 \\
\hline 3 & 19.8 & 113 & 102 & 102 & 101 & 118 & 115 & 23.364 & 22.770 & 115 & 26.8686 & 26.185 \\
\hline 4 & 21 & 113 & 102 & 102 & 101 & 118 & 115 & 24.780 & 24.150 & 115 & 28.497 & 27.772 \\
\hline 5 & 20.1 & 113 & 102 & 102 & 101 & 118 & 115 & 23.718 & 23.115 & 115 & 27.2757 & 26.582 \\
\hline 6 & 21.2 & 113 & 102 & 102 & 101 & 118 & 115 & 25.016 & 24.380 & 115 & 28.7684 & 28.037 \\
\hline 7 & 20.1 & 113 & 102 & 102 & 101 & 118 & 115 & 23.718 & 23.115 & 115 & 27.2757 & 26.582 \\
\hline 8 & 20.4 & 113 & 102 & 102 & 101 & 118 & 115 & 24.072 & 23.460 & 115 & 27.6828 & 26.979 \\
\hline 9 & 20.3 & 113 & 102 & 102 & 101 & 118 & 115 & 23.954 & 23.345 & 115 & 27.5471 & 26.846 \\
\hline 10 & 21.2 & 113 & 102 & 102 & 101 & 118 & 115 & 25.016 & 24.380 & 115 & 28.7684 & 28.037 \\
\hline 11 & 21 & 113 & 102 & 102 & 101 & 118 & 115 & 24.780 & 24.150 & 115 & 28.497 & 27.772 \\
\hline 12 & 20.8 & 113 & 102 & 102 & 101 & 118 & 115 & 24.544 & 23.920 & 115 & 28.2256 & 27.508 \\
\hline 13 & 19.7 & 113 & 102 & 102 & 101 & 118 & 115 & 23.246 & 22.655 & 115 & 26.7329 & 26.053 \\
\hline 14 & 20.2 & 113 & 102 & 102 & 101 & 118 & 115 & 23.836 & 23.230 & 115 & 27.4114 & 26.714 \\
\hline 15 & 21.2 & 113 & 102 & 102 & 101 & 118 & 115 & 25.016 & 24.380 & 115 & 28.7684 & 28.037 \\
\hline
\end{tabular}

In Table 5, the values of the 15 observations discussed for the cutting process are measured. For example, while the first observation is calculated as approximately 27 seconds according to CWM, this value is calculated as 26.3 seconds according to
FWM. The difference between the averages of the 15 observations is calculated as 0.705 seconds, and this difference is very low since the cutting process is a short process.

Table 6

Normal and Standard time for universal milling process according to CWM and FWM

\begin{tabular}{|c|c|c|c|c|c|c|c|c|c|c|c|c|}
\hline Obs. & $\begin{array}{l}\text { Obs. } \\
\text { Time for } \\
\text { Universal } \\
\text { Milling }\end{array}$ & Skill & Effort & $\begin{array}{l}\text { Env. } \\
\text { Cond. }\end{array}$ & Cons. & $\begin{array}{l}\text { Performance } \\
\text { Value for CWM }\end{array}$ & $\begin{array}{l}\text { Performance } \\
\text { Value for FWM }\end{array}$ & $\begin{array}{l}\text { Normal } \\
\text { Time for } \\
\text { CWM }\end{array}$ & $\begin{array}{l}\text { Normal } \\
\text { Time for } \\
\text { FWM }\end{array}$ & Tolerance & $\begin{array}{l}\text { Std. Time } \\
\text { for CWM }\end{array}$ & $\begin{array}{l}\text { Std. Time } \\
\text { for FWM }\end{array}$ \\
\hline 1 & 480.1 & 103 & 108 & 104 & 104 & 119 & 120 & 571.319 & 576.12 & 115 & 657.017 & 662.538 \\
\hline 2 & 475.8 & 103 & 108 & 104 & 104 & 119 & 120 & 566.202 & 570.96 & 116 & 656.794 & 662.314 \\
\hline 3 & 475.6 & 103 & 108 & 104 & 104 & 119 & 120 & 565.964 & 570.72 & 117 & 662.178 & 667.742 \\
\hline 4 & 480.3 & 103 & 108 & 104 & 104 & 119 & 120 & 571.557 & 576.36 & 118 & 674.437 & 680.105 \\
\hline 5 & 480.5 & 103 & 108 & 104 & 104 & 119 & 120 & 571.795 & 576.60 & 119 & 680.436 & 686.154 \\
\hline 6 & 475.8 & 103 & 108 & 104 & 104 & 119 & 120 & 566.202 & 570.96 & 120 & 679.442 & 685.152 \\
\hline 7 & 476.7 & 103 & 108 & 104 & 104 & 119 & 120 & 567.273 & 572.04 & 121 & 686.400 & 692.168 \\
\hline 8 & 479.4 & 103 & 108 & 104 & 104 & 119 & 120 & 570.486 & 575.28 & 122 & 695.993 & 701.842 \\
\hline 9 & 481.9 & 103 & 108 & 104 & 104 & 119 & 120 & 573.461 & 578.28 & 123 & 705.357 & 711.284 \\
\hline 10 & 481.7 & 103 & 108 & 104 & 104 & 119 & 120 & 573.223 & 578.04 & 124 & 710.797 & 716.770 \\
\hline 11 & 475.8 & 103 & 108 & 104 & 104 & 119 & 120 & 566.202 & 570.96 & 125 & 707.753 & 713.700 \\
\hline 12 & 479.4 & 103 & 108 & 104 & 104 & 119 & 120 & 570.486 & 575.28 & 126 & 718.812 & 724.853 \\
\hline 13 & 480.3 & 103 & 108 & 104 & 104 & 119 & 120 & 571.557 & 576.36 & 127 & 725.877 & 731.977 \\
\hline 14 & 480.1 & 103 & 108 & 104 & 104 & 119 & 120 & 571.319 & 576.12 & 128 & 731.288 & 737.434 \\
\hline 15 & 480.5 & 103 & 108 & 104 & 104 & 119 & 120 & 571.795 & 576.60 & 129 & 737.616 & 743.814 \\
\hline
\end{tabular}

In Table 6 , the values of the 15 observations discussed for the universal milling process are measured. For example, while the first observation is calculated as approximately 657 seconds according to CWM, this value is calculated as 662,5 seconds according to FWM. The difference between the averages of the 15 observations is calculated as 5.8 seconds 
Table 7

Normal and Standard time for CNC processing process according to CWM and FWM

\begin{tabular}{|c|c|c|c|c|c|c|c|c|c|c|c|c|}
\hline Obs. & $\begin{array}{c}\text { Obs. } \\
\text { Time for } \\
\text { CNC } \\
\text { Processing }\end{array}$ & Skill & Effort & $\begin{array}{l}\text { Env. } \\
\text { Con. }\end{array}$ & Cons. & $\begin{array}{l}\text { Performance } \\
\text { Value for } \\
\text { CWM }\end{array}$ & $\begin{array}{l}\text { Performance } \\
\text { Value for } \\
\text { FWM }\end{array}$ & $\begin{array}{l}\text { Normal } \\
\text { Time for } \\
\text { CWM }\end{array}$ & $\begin{array}{l}\text { Normal } \\
\text { Time for } \\
\text { FWM }\end{array}$ & Tolerance & $\begin{array}{l}\text { Std. } \\
\text { Time for } \\
\text { CWM }\end{array}$ & $\begin{array}{l}\text { Std. } \\
\text { Time for } \\
\text { FWM }\end{array}$ \\
\hline 1 & 298.3 & 106 & 105 & 104 & 101 & 116 & 112 & 346.028 & 334.096 & 115 & 397.932 & 384.210 \\
\hline 2 & 302.1 & 106 & 105 & 104 & 101 & 116 & 112 & 350.436 & 338.352 & 116 & 406.506 & 392.488 \\
\hline 3 & 301.2 & 106 & 105 & 104 & 101 & 116 & 112 & 349.392 & 337.344 & 117 & 408.789 & 394.692 \\
\hline 4 & 300.8 & 106 & 105 & 104 & 101 & 116 & 112 & 348.928 & 336.896 & 118 & 411.735 & 397.537 \\
\hline 5 & 302.9 & 106 & 105 & 104 & 101 & 116 & 112 & 351.364 & 339.248 & 119 & 418.123 & 403.705 \\
\hline 6 & 299.1 & 106 & 105 & 104 & 101 & 116 & 112 & 346.956 & 334.992 & 120 & 416.347 & 401.990 \\
\hline 7 & 298.9 & 106 & 105 & 104 & 101 & 116 & 112 & 346.724 & 334.768 & 121 & 419.536 & 405.069 \\
\hline 8 & 298.5 & 106 & 105 & 104 & 101 & 116 & 112 & 346.26 & 334.320 & 122 & 422.437 & 407.870 \\
\hline 9 & 301.3 & 106 & 105 & 104 & 101 & 116 & 112 & 349.508 & 337.456 & 123 & 429.895 & 415.071 \\
\hline 10 & 301.2 & 106 & 105 & 104 & 101 & 116 & 112 & 349.392 & 337.344 & 124 & 433.246 & 418.307 \\
\hline 11 & 299.3 & 106 & 105 & 104 & 101 & 116 & 112 & 347.188 & 335.216 & 125 & 433.985 & 419.020 \\
\hline 12 & 299.6 & 106 & 105 & 104 & 101 & 116 & 112 & 347.536 & 335.552 & 126 & 437.895 & 422.796 \\
\hline 13 & 301.2 & 106 & 105 & 104 & 101 & 116 & 112 & 349.392 & 337.344 & 127 & 443.728 & 428.427 \\
\hline 14 & 302 & 106 & 105 & 104 & 101 & 116 & 112 & 350.32 & 338.240 & 128 & 448.410 & 432.947 \\
\hline 15 & 302.3 & 106 & 105 & 104 & 101 & 116 & 112 & 350.668 & 338.576 & 129 & 452.362 & 436.763 \\
\hline
\end{tabular}

In Table 7 , the values of the 15 observations discussed for the CNC processing process are measured. For example, while the first observation is calculated as 397.9 seconds according to CWM, this value is calculated as 384.2 seconds according to FWM. The difference between the averages of the 15 observations is calculated as 14.6 seconds.

Table 8

Normal and Standard time for universal milling process according to CWM and FWM

\begin{tabular}{|c|c|c|c|c|c|c|c|c|c|c|c|c|}
\hline Obs. & $\begin{array}{c}\text { Obs. } \\
\text { Time for } \\
\text { Universal } \\
\text { Milling }\end{array}$ & Skill & Effort & $\begin{array}{l}\text { Env. } \\
\text { Cond. }\end{array}$ & Consis. & $\begin{array}{l}\text { Performance } \\
\text { Value for } \\
\text { CWM }\end{array}$ & $\begin{array}{l}\text { Performance } \\
\text { Value for } \\
\text { FWM }\end{array}$ & $\begin{array}{l}\text { Normal } \\
\text { Time for } \\
\text { CWM }\end{array}$ & $\begin{array}{l}\text { Normal } \\
\text { Time for } \\
\text { FWM }\end{array}$ & Tolerance & $\begin{array}{l}\text { Std. } \\
\text { Time } \\
\text { for } \\
\text { CWM }\end{array}$ & $\begin{array}{l}\text { Std. Time } \\
\text { for FWM }\end{array}$ \\
\hline 1 & 70.2 & 111 & 105 & 102 & 103 & 121 & 119 & 84.942 & 83.538 & 115 & 97.683 & 96.069 \\
\hline 2 & 69.9 & 111 & 105 & 102 & 103 & 121 & 119 & 84.579 & 83.181 & 116 & 98.112 & 96.490 \\
\hline 3 & 68.3 & 111 & 105 & 102 & 103 & 121 & 119 & 82.643 & 81.277 & 117 & 96.692 & 95.094 \\
\hline 4 & 73.1 & 111 & 105 & 102 & 103 & 121 & 119 & 88.451 & 86.989 & 118 & 104.372 & 102.647 \\
\hline 5 & 73.4 & 111 & 105 & 102 & 103 & 121 & 119 & 88.814 & 87.346 & 119 & 105.689 & 103.942 \\
\hline 6 & 70.6 & 111 & 105 & 102 & 103 & 121 & 119 & 85.426 & 84.014 & 120 & 102.511 & 100.817 \\
\hline 7 & 70.3 & 111 & 105 & 102 & 103 & 121 & 119 & 85.063 & 83.657 & 121 & 102.926 & 101.225 \\
\hline 8 & 70.1 & 111 & 105 & 102 & 103 & 121 & 119 & 84.821 & 83.419 & 122 & 103.482 & 101.771 \\
\hline 9 & 68.7 & 111 & 105 & 102 & 103 & 121 & 119 & 83.127 & 81.753 & 123 & 102.246 & 100.556 \\
\hline 10 & 67 & 111 & 105 & 102 & 103 & 121 & 119 & 81.070 & 79.730 & 124 & 100.527 & 98.865 \\
\hline 11 & 70.3 & 111 & 105 & 102 & 103 & 121 & 119 & 85.063 & 83.657 & 125 & 106.329 & 104.571 \\
\hline 12 & 73.1 & 111 & 105 & 102 & 103 & 121 & 119 & 88.451 & 86.989 & 126 & 111.448 & 109.606 \\
\hline 13 & 72.3 & 111 & 105 & 102 & 103 & 121 & 119 & 87.483 & 86.037 & 127 & 111.103 & 109.267 \\
\hline 14 & 70.1 & 111 & 105 & 102 & 103 & 121 & 119 & 84.821 & 83.419 & 128 & 108.571 & 106.776 \\
\hline 15 & 69.9 & 111 & 105 & 102 & 103 & 121 & 119 & 84.579 & 83.181 & 129 & 109.107 & 107.303 \\
\hline
\end{tabular}

In Table 8 , the values of the 15 observations discussed for the universal milling process are measured. For example, while the first observation is calculated as 97.6 seconds according to CWM, this value is calculated as 96 seconds according to FWM. The difference between the averages of the 15 observations is calculated as 1.7 seconds. 
Table 9

Normal and Standard time for metal blackening process according to CWM and FWM

\begin{tabular}{|c|c|c|c|c|c|c|c|c|c|c|c|c|}
\hline Obs. & $\begin{array}{c}\text { Obs. } \\
\text { Time for } \\
\text { Metal } \\
\text { Blackening }\end{array}$ & Skill & Effort & $\begin{array}{l}\text { Env. } \\
\text { Cond. }\end{array}$ & Cons. & $\begin{array}{l}\text { Performance } \\
\text { Value for } \\
\text { CWM }\end{array}$ & $\begin{array}{l}\text { Performance } \\
\text { Value for } \\
\text { FWM }\end{array}$ & $\begin{array}{l}\text { Normal } \\
\text { Time for } \\
\text { CWM }\end{array}$ & $\begin{array}{l}\text { Normal } \\
\text { Time for } \\
\text { FWM }\end{array}$ & Tolerance & $\begin{array}{l}\text { Std. } \\
\text { Time } \\
\text { for } \\
\text { CWM }\end{array}$ & $\begin{array}{l}\text { Std. Time } \\
\text { for FWM }\end{array}$ \\
\hline 1 & 120.1 & 100 & 105 & 93 & 98 & 96 & 95 & 115.296 & 114.095 & 115 & 132.590 & 131.209 \\
\hline 2 & 118.3 & 100 & 105 & 93 & 98 & 96 & 95 & 113.568 & 112.385 & 116 & 131.739 & 130.367 \\
\hline 3 & 122.1 & 100 & 105 & 93 & 98 & 96 & 95 & 117.216 & 115.995 & 117 & 137.143 & 135.714 \\
\hline 4 & 119.3 & 100 & 105 & 93 & 98 & 96 & 95 & 114.528 & 113.335 & 118 & 135.143 & 133.735 \\
\hline 5 & 118 & 100 & 105 & 93 & 98 & 96 & 95 & 113.28 & 112.100 & 119 & 134.803 & 133.399 \\
\hline 6 & 122.8 & 100 & 105 & 93 & 98 & 96 & 95 & 117.888 & 116.660 & 120 & 141.466 & 139.992 \\
\hline 7 & 120.8 & 100 & 105 & 93 & 98 & 96 & 95 & 115.968 & 114.760 & 121 & 140.321 & 138.860 \\
\hline 8 & 121.9 & 100 & 105 & 93 & 98 & 96 & 95 & 117.024 & 115.805 & 122 & 142.769 & 141.282 \\
\hline 9 & 118.6 & 100 & 105 & 93 & 98 & 96 & 95 & 113.856 & 112.670 & 123 & 140.043 & 138.584 \\
\hline 10 & 119.3 & 100 & 105 & 93 & 98 & 96 & 95 & 114.528 & 113.335 & 124 & 142.015 & 140.535 \\
\hline 11 & 121.9 & 100 & 105 & 93 & 98 & 96 & 95 & 117.024 & 115.805 & 125 & 146.280 & 144.756 \\
\hline 12 & 119.6 & 100 & 105 & 93 & 98 & 96 & 95 & 114.816 & 113.620 & 126 & 144.668 & 143.161 \\
\hline 13 & 120.2 & 100 & 105 & 93 & 98 & 96 & 95 & 115.392 & 114.190 & 127 & 146.548 & 145.021 \\
\hline 14 & 119.8 & 100 & 105 & 93 & 98 & 96 & 95 & 115.008 & 113.810 & 128 & 147.210 & 145.677 \\
\hline 15 & 119.9 & 100 & 105 & 93 & 98 & 96 & 95 & 115.104 & 113.905 & 129 & 148.484 & 146.937 \\
\hline
\end{tabular}

In Table 9, the values of the 15 observations discussed for the metal blackening process are measured. For example, while the first observation is calculated as 132.5 seconds according to CWM, this value is calculated as 131.2 seconds according to FWM. The difference between the averages of the 15 observations is calculated as 1.5 seconds.

\section{Conclusion}

The main cost items of a company are material cost and labor cost. The daily production amount is effective in the labor cost of a part. Proper evaluation of the performance of the worker involved in a process will benefit at many points. The first one is the correct calculation of labor costs, daily production quantities, deadlines and fair management of the wage-price policies. As a result of performance evaluations, low performance workers can be trained to increase their performance levels. Calculating operator's performance with minimum error is an advantage for companies because of providing the correct calculation of salary management (salary policy, overtime work), production volume (supplydemand balance). However, tempo rating methods may not be sufficient to reflect the actual performance of the workers. Especially in methods based on the observation of the decision maker, finding the numerical equivalent of linguistic expressions and adding them to the calculations can be challenging. Thanks to the fuzzy logic approach, errors that may occur due to the individual opinion of the observer can be minimized.
In this study, the performance rating approach of CWM is discussed with the fuzzy logic approach. The proposed FWM is applied to the company that produces automatic cutting machines in order to provide its validity. Obtaining more sensitive values with the proposed method will result in more accurate calculations in the studies where these values will be used. For example, when Table 7 is examined, the difference between the average of 15 observations according to CWM and the average according to FWM is determined as approximately 15 seconds. With the FWM approach, a lower standard time of about 15 seconds is achieved. Although this value seems to be a small difference when considering 1 product, its effect will increase as the number of products increases. In addition, differences arising from other operations increase the amount of error on the total standard time. In the study, performance values are calculated for each process separately. However, the tolerance value is pre-determined as $115 \%$ and is used in the calculation of standard times. This approach has been adopted to determine the limits of the study. However, tolerance values vary according to the working position of the operators, the weight of the work piece, environmental conditions and the mental and physical fatigue it creates. In cases where the tolerance value will be calculated separately, healthier results can be obtained thanks to the fuzzy logic approach. In the future study, a fuzzy-based approach may be proposed for calculating tolerance values. In this way, processbased tolerance values can be determined. 


\section{Acknowledgements}

This paper is an extension of a conference paper entitled "Fuzzy Westinghouse Tempo Rating System: A Case Study in an Automotive Company" that published in Conference Proceedings of "10th International Symposium on Intelligent Manufacturing and Service Systems (IMSS'19)".

\section{Contribution of Researchers}

Determination of the problem, deciding on the solution method, and application of the proposed method were realized by all authors simultaneously. Merve Cengiz Toklu and Alper Kiraz were prepared manuscript formatting and editing.

\section{Conflict of Interest}

We have no conflict of interest to declare.

\section{References}

Barnes, R. M. (1980). Motion and Time StudyDesign and Measurement of Work (7th Edition), Wiley, New York, ISBN: 978-0-471-05905-9. Retrieved from https://www.wiley.com/enus/Motion+and+Time+Study $\% 3 \mathrm{~A}+$ Design+and+ Measurement+of+Work\%2C+7th+Edition-p$\underline{9780471059059}$

Bircan, H., \& İskender, G. (2005). İş Ölçümü Tekniklerinden Zaman Etüdü Üzerine Bir Uygulama. Cumhuriyet Üniversitesi Íktisadi ve Ídari Bilimler Dergisi, 6(2), 199-219. Retrieved from http://eskidergi.cumhuriyet.edu.tr/ makale/1228.pdf

Çevikcan, E., \& Kılıç, H. S. (2016). Tempo rating approach using fuzzy rule based system and westinghouse method for the assessment of normal time. International Journal of Industrial Engineering: Theory Applications and Practice, 23(1), pp. 49-67. Retrieved from https://journals.sfu.ca/ijietap/index.php/ijie/ article/view/1584

Çevikcan, E., Kılıç, H. S., \& Zaim, S. (2012). Westinghouse method oriented fuzzy rule based tempo rating approach. In Proc. Proceedings of the 2012 International Conference on Industrial Engineering and Operations Management, Istanbul, Turkey (pp. 1670-1677).

Chebolu-Subramanian, V., Sule, N., Sharma, R., \& Mistry, N. (2019). A time motion study of community mental health workers in rural India. BMC health services research, 19(1), 878. DOI: $\quad$ https://doi.org/10.1186/s12913-019$\underline{4732-7}$

Kanawaty, G. (1992). Introduction to Work Study. Fourth (revised) edition. International Labour Office, Geneva. ISBN: 92-2-107108-1.

Lehto, M. R., \& Landry, S. J. (2012). Introduction to Human Factors and Ergonomics for Engineers. Taylor \& Francis Group, CRC Press. ISBN-10 : 1439853940, ISBN-13 : 978-1439853948.

Mamdani, E. H., \& Assilian, S. (1975). An experiment in linguistic synthesis with a fuzzy logic controller. International journal of man-machine studies, 7(1), 1-13. DOI: https://doi.org/ 10.1016/S0020-7373(75)80002-2

Matias, A. C. (2001). Work Measurement: Principles and Techniques. New York, USA: John Wiley \& Sons. DOI: https://doi.org/10.1002/ 9780470172339.ch54

Namazov, M., \& Bastürk, O. (2010). DC Motor Position Control Using Fuzzy ProportionalDerivative Controllers With Different Defuzzification Methods. TJFS: Turkish Journal of Fuzzy Systems, 1(1), 36-54. eISSN: 1309-1190.

Pourjavad, E., \& Mayorga, R. V. (2019). A comparative study and measuring performance of manufacturing systems with Mamdani fuzzy inference system. Journal of Intelligent Manufacturing, $\quad 30(3), \quad 1085-1097 . \quad$ DOI: https://doi.org/10.1007/s10845-017-1307-5

Suwittayaruk, P., \& Van Goubergen, D. (2011). A tool to visualize response selection and execution on pace rating. In 9th International Industrial Simulation Conference. pp. 26-30. EUROSIS-ETI Publications. 